\title{
Tourists' perceptions of beach quality improvement during the off-peak season: a segmentation approach
}

\author{
Perceção dos turistas sobre a melhoria da qualidade da praia na época baixa: uma abordagem por segmentação
}

Goda Lukoseviciute

Universidade do Algarve, Research Centre for Tourism, Sustainability and Well-being, Portugal, glukoseviciute@ualg.pt

\section{Luís Nobre Pereira}

Universidade do Algarve, Escola Superior de Gestão, Hotelaria e Turismo \& Research Centre for Tourism, Sustainability and Wellbeing, Portugal, Lmper@ualg.pt

Received: 10.06.2020; Revisions required: 17.9.2020; Accepted: 05.01.2021

\begin{abstract}
Recently coastal tourism has increased rapidly and has negatively affected environmental, social and cultural sustainability. The Algarve is the main sun-and-sea tourism destination in Portugal, with a large number of beautiful beaches. Due to negative tourism impacts and climate change, coastal tourism management tools need to be assessed and implemented. Most beach areas have the dual mandate of conserving coastal natural resources and providing opportunities for recreation and tourism. This paper aims to identify off-peak season beach users' profiles and to segment them according to their priorities for sustainable beach management in the face of climate change and seasonality balance. Four beaches with different types were chosen in the municipality of Albufeira as case studies: an urban, a rural, a resort and a remote beach. A cluster analysis was applied to data collected through a survey applied to 200 tourists through face-to-face interviews. The survey aimed to measure beach visitors' opinion about beach environment and services, as well as about the importance of 25 quality beach attributes. The cluster analyses generated three segments of beach users with the following profiles: comfort and food lovers, young and active environmentalists and sustainable minimalists. The results provide valuable information and insights for both academics and beach managers, who can adjust their management tasks to suit market segments and their preferences, fulfilling emerging environmental policies.
\end{abstract}

Keywords: Segmentation, sustainable beach management, beach users' perception, beach quality.

\section{Resumo}

O turismo costeiro cresceu de forma acelerada e tem vindo a afetar negativamente a sustentabilidade ambiental, social e cultural. O Algarve é o principal turístico destino de sol e praia em Portugal, tendo um grande número de praias. Devido aos impactos negativos do turismo e às alterações climáticas, torna-se necessário avaliar e implementar ferramentas de gestão do turismo costeiro. A maioria das áreas de praia tem o duplo desígnio de conservação dos recursos naturais e de oferta de oportunidades para atividades de turismo e de lazer. Este artigo tem como objetivos identificar o perfil dos utilizadores da praia na época baixa e segmentá-los de acordo com as suas prioridades para a gestão sustentável da praia. Foram escolhidas quatro praias de diferentes tipos: uma urbana, uma rural, uma remota e uma praia de empreendimento turístico. Foi aplicada uma análise de clusters aos dados recolhidos através de um inquérito por questionário aplicado a 200 turistas por entrevista pessoal. $\mathrm{O}$ inquérito visava medir a opinião dos utilizadores da praia sobre o ambiente e os serviços da praia, bem como sobre a importância de 25 atributos de qualidade da praia. A análise de clusters permitiu identificar três segmentos: amantes do conforto e da comida, ambientalistas jovens e ativos, e minimalistas sustentáveis. Os resultados fornecem informações valiosas não só para investigadores, mas também para gestores de praia, os quais podem ajustar as suas tarefas de gestão para satisfazerem os segmentos de mercado e suas preferências, atendendo a políticas ambientais emergentes.

Palavras-chave: Segmentação, gestão sustentável da Praia, perceção dos utilizadores da Praia, qualidade da praia.

\section{Introduction}

Recently the United Nations World Tourism Organization (UNWTO) declared that tourism has become one of the fastestgrowing sectors, where coastal areas have become preferred destinations for many holidaymakers in Europe and abroad (European Commission, 2014). The number of coastal tourists increases around the world, which is expected to reach 1.56 billion (Tovar-Sánchez \& Sánchez-Quiles, 2015), directly impacting the global economy and nations' development, and it is impacting the social, cultural, environmental and political sectors.

In coastal tourism, beaches are an essential element and a valuable resource for sun and sea tourism. Large, clean and gleaming beaches scaled by clean ocean water are the tourists' main priority. However, intensive recreation and climate change have changed the visual image of beaches because of coastal erosion, water and sand pollution, deterioration and coastal dune degradation (Semeoshenkova \& Newton, 2015), which is reflected through reduced beach-carrying capacity, constraining the resilience of coastal erosion (Samora-Arvela et al., 2017). In general, massive tourism is inevitably linked to ecosystems (Dempsey and Roberston, 2012), changing their dynamics and accelerating habitat fragmentation.

A key problem, according to much of the literature, is the impact of sea-level rise, particularly for Mediterranean regions (Aucelli et al., 2017; Kantogianni et al., 2014; Snoussi et al., 2008), which largely rely on coastal tourism and recreational activities. With the sea-level rise, coastal infrastructure will be more vulnerable (Jones and Phillips, 2006), considering that metropolitan beach infrastructure is often too close to the active coastline and requires the adoption of protective measures (Thompson and Schlacher, 2012). These undesirable side effects have given rise to increasing concerns about the conservation of natural 
resources as well as about human well-being and the long-term economic viability of communities.

Depending on the impact of tourism on the coastline, the European Commission has adopted a recommendation for the implementation of Integrated Coastal Zone Management (ICZM) (2002/413/EC), which aims to balance multiple human activities and demands on coastal space and resources with the protection of dynamic and vulnerable coastal systems and the maintenance of the functions and services which they provide (Humphrey \& Burbridge, 1999). As global practices have shown (Batista et al., 2020; Koutrakis et al., 2011; Marzetti et al., 2016), the first steps of ICZM application are usually decided upon while taking into account beach user priorities and their general opinion with regard to planned site changes. This phase is important for keeping up tourism flows that in touristic regions mainly drive the economy and for showing sustainable solidarity, which has recently been identified as a key factor of tourism competitiveness (Rodríguez-Díaz \& Pulido-Fernández, 2020).

The region of Algarve, located in the southern part of Portugal, is the most popular tourism destination for international visitors, with numerous popular resorts (Antunes, 2000); it is valued for its Mediterranean climate, with more than 120 sunny days per year. Algarve is mainly focused on tourism as its single and dominant activity, which mainly drives the region's economy, accounting for $15 \%$ of the total country GDP (Semeoshenkova and Newton, 2015). One of the most tourist-attracting features of the Algarve region is unique coastal diversity in various types of beaches, starting from sandy remote to pocket rural, located in between cliffs and urban resorts. According to Neto et al. (2013), four main types of coasts can be distinguished along the Portuguese continental coastline: low sandy beaches, cliffs, littoral wetlands and artificial coasts.

However, the beaches are highly vulnerable as they are mostly in lowland areas (Martins et al., 2012; Cabral et al., 2012) and have been greatly affected by urbanisation, which has occurred along the coastline (Alves et al., 2017; Botequilha-Leitao et al., 2014). Vaz et al. (2012) have predicted a continuing city development along the ocean in Algarve, raising problematic questions of coastal ecosystem conservation, classified as highly vulnerable. With a transition to a high-quality tourism paradigm, specifically golf resort development, remote areas have been occupied, and ecosystem services deteriorated, resulting in increased water consumption and pollution (Thiel, 2010).

Therefore, the regional beach management in Algarve is currently attempting to solve two main issues: the threat of climate change, which according to Fereira et al. (2008) and Nunes et al. (2009) threatens sandy shores and rocky cliffs, and peak and offpeak seasonality management balance, since Algarve, like other coastal tourism destinations, sees a big difference in the number of visiting tourists between peak and off-peak seasons (Corluka et al., 2016). Studies addressing tourists' appreciation of the same tourism destination in different seasons are scarce (Barreira \& Cesário, 2018). However, seasonality is inevitable (Andriotis,
2005), directly linked to climate, weather (Scott et al., 2004), social pressure and fashion factors (Butler, 1994), determining tourist behaviour and visitor types. Therefore destination management should be balanced between those two seasons in a sustainable manner, creating positive economic, environmental and social effects.

Given coastal tourism trends in Algarve, the aims of the present study are twofold: i) to identify off-peak season beach users' profiles, and ii) to segment beach users according to their priorities for sustainable beach management in the face of climate change and seasonality balance. The user preferences survey was used to identify priorities based on visitor segmentation, which will lead to a more efficient allocation of resources and optimisation of coastal zone management. This study contributes to the segmentation literature and to beach management balancing during the off-peak season.

\section{Literature review of segmentation in tourism}

The heterogeneity feature, which distinguishes individuals based on their characteristics, was first expressed in the form of clusters in the field of anthropology (Driver \& Kroeber, 1932). Later, clustering was globally recognised as an important tool for better understanding heterogeneity and one that leads to more efficient marketing (Wallace et al., 2013), tourism destination management (Ramires et al., 2018), general tourism development (Harrill et al., 2010), economy balance (Antonakakis et al., 2017), life quality assessment (Ferreira et al., 2016) and even clinical treatment (Windgassen et al., 2018).

In tourism studies, understanding consumer needs and behaviour is crucial. Segmentation, as a powerful marketing tool, makes it possible to extract tourist identities, focus on them and identify customer preferences (McCleary, 1995). Thus, motivation has been a key clustering variable, widely applied for various tourism destinations (Albayrak \& Caber, 2018; Fung \& Jim, 2015; Guttentag et al., 2018; Loker-Murphy, 1997; Ramires et al., 2018), that explains tourists' decisions as well as their needs. As a result, very often, clustering is based on another parallel measurement of satisfaction of destination attributes, applied in combination with the Importance-Performance technique (Bruyere et al., 2002; Vaske et al., 1996; Wade \& Eagles, 2003). Indeed, motivation-based clustering usually aims to identify tourists' interests, behaviour and expectations, leading towards innovative touristic products and services development and providing integrated, wide-ranging, fulfilling and memorable experiences (Ramires et al., 2018). By contrast, clustering based on the importance of attributes focuses on resource allocation and quality of services that visitors value the most (Vaske et al., 1996).

With the focus on the narrower market of beach visitors and issues related to coastal area management, previous studies analysing beach user perceptions of sustainable management have increased in the last decades in order to understand beach users' behaviour, needs and preferences, which is essential for market segmentation. Therefore, very often, researchers have 
combined variables of facilities, services and environmental aspects in the questionnaire, asking beach visitors how important it is for them to have beach facilities such as showers, toilets, litter bins, access for disabled people, parking, debris removal, clean seawater, clean beach, safety, aesthetics of landscape, crowdedness and sports activities (Lindsay et al., 1992; Marin et al., 2009; Roca \& Villares, 2008; Santos et al., 2005; Smith et al., 1991; Snider et al., 2015; Williams \& Nelson, 1997). These variables have been recognised as the most instrumental in assessing the local situation and developing strategies for sustainable management of local beaches and has proved helpful in avoiding the decline of the area as a tourism destination, which is vital for regions such as Algarve.

\section{Research methodology}

\subsection{Study area}

The region of Algarve is in southern Portugal, whose shores are riveted by the Atlantic Ocean. The region is a major tourism destination in the whole country due to its privileged location, mild climate throughout the year, with an average temperature in winter of about $14^{\circ} \mathrm{C}$ and in summer of about $24^{\circ} \mathrm{C}$ (Williams \& Semeoshenkova, 2011), the natural conditions related to the sea, environment, heritage and gastronomy. The four case study beaches representing four different types of environments are in the municipality of Albufeira (Figure 1), which is a rich, tourismdominated local authority with the highest incomes from tourism (Thiel, 2010). All four beaches described below are certified by the Blue Flag by the Foundation of Environmental Education.
Praia dos Pescadores is a typical urban beach, located directly opposite Albufeira old town and surrounded by dwellings, apartments, shops, cafés, restaurants, market and banks. It is the most popular beach during the peak season, with high provision of lifeguards, showers, sunbeds, umbrellas and water sports equipment, and most of the services are for free. The beach is accessible from the city side, and has an elevator and escalator for disabled people.

Praia de Santa Eulalia represents a resort-type beach located 4.7 $\mathrm{km}$ east of Albufeira, and is remarkable for a 5-star hotel, an exotic natural landscape and a golden sand rural beach. During the high season, the beach is equipped with showers and toilets for a fee. The beach is accessible on foot, by public or private transportation, with good access for disabled people and a spacious parking area.

Praia dos Olhos d'Agua represents a typical rural beach; it is located on the coast of Olhos d'Agua village, surrounded by a few dwelling houses and cafés in between rocky shores with vast swathes of sand within walking distance of the village. During the peak season, there is a provision of showers and public toilets for a fee. The beach is accessible only by private transport, but parking is available far away from the beach.

Praia da Falesia is a typical remote beach and the longest in Algarve. The beach is accessible only by private transport and has a small parking area. The beach is dominated by orange cliffs and unique wildlife. During the peak season, there is a provision of sun loungers, umbrellas, toilets and showers for a fee.

\section{Figure 1 - Location of case study beaches in the municipality of Albufeira}

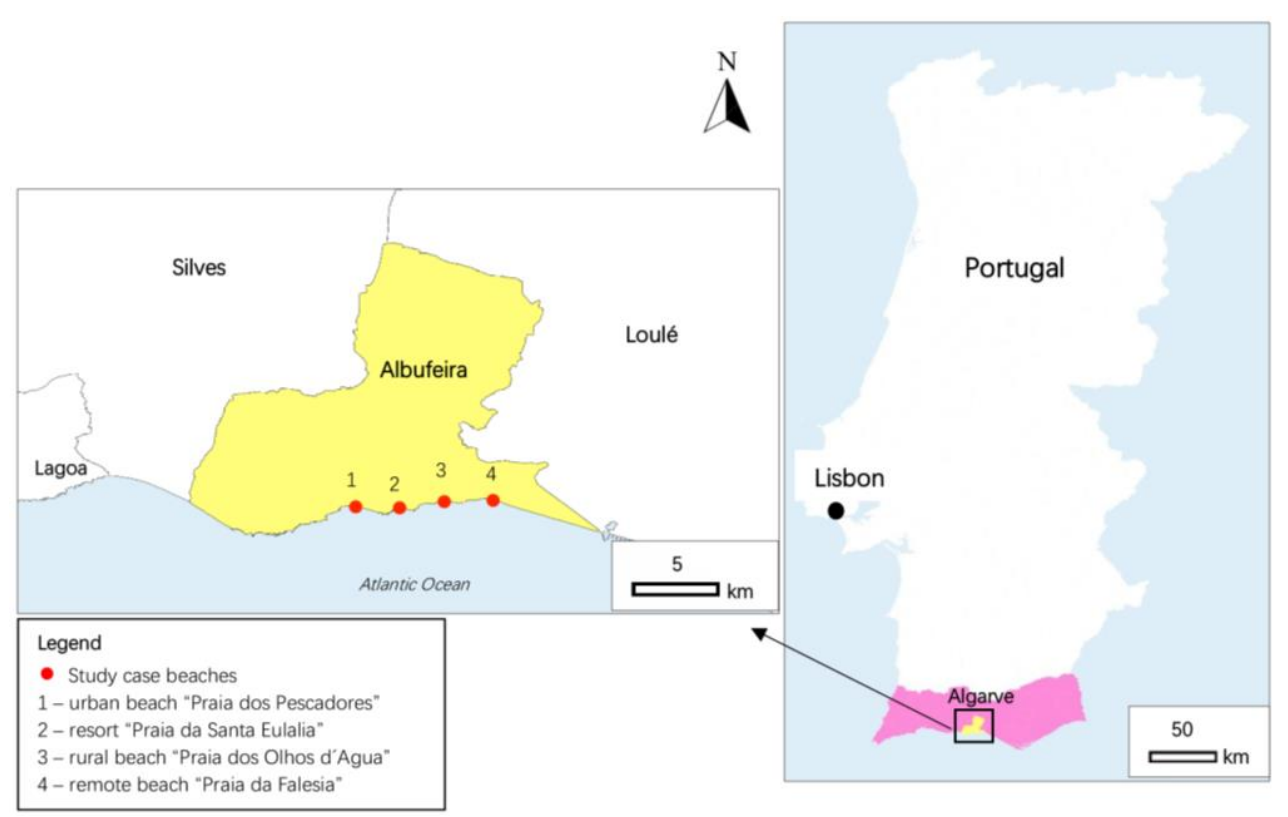

Source: Own elaboration.

\subsection{Sample and data collection}

The target population of this research was defined as all national and international beach visitors, aged 18 or older, not living in the study area and able to communicate in English, Spanish, Portuguese, French or German. According to the Portuguese National Statistics Institute (INE, 2018), 71\% of tourists in Portugal are from international markets, where the first five 
biggest groups are British (20\%), German (14\%), Spanish (10\%), French (10\%) and Brazilian (5\%) tourists.

The convenience sampling technique was used to select a sample because there is not a sampling frame of the target population and because it is usually used in exploratory research. We assumed that the population size is unknown; therefore, following previous research recommendations, to make our sample more heterogeneous and increase its representativeness at the destination level (Tampakis et al., 2018; Williams \& Micallef, 2009), 50 participants from each selected beach were chosen to be interviewed (200 participants in total for all four beaches) in face-to-face interviews. The most significant criteria for the selection of our survey cases was the existence of four different representative types of beaches in the municipality of Albufeira.

The questionnaire was administered during the visitors' stay at the beach. Respondents were approached at random. The average time spent per interview was 15 minutes, during which additional comments were requested that may highlight other aspects not included in the questionnaire. Surveys were carried out during January and May of 2018, between 11:00 and 16:00 hours. One research assistant, who was able to communicate in English, French and German, was trained to conduct the interviews with foreign beach visitors.

\subsection{Questionnaire design}

A structured questionnaire was designed to assess beach visitors' experiences, uses and behaviour on the case study beaches and to segment visitors into groups. The questionnaire was designed in English, Spanish, French and Portuguese. The questionnaire was comprised of three main parts, consisting of a combination of different types of questions: closed-ended questions (yes/no, multiple-choice and Likert scale), as well as open-ended questions. In total, the first and second parts contained 15 questions that were drawn up based on a study conducted by Alves et al. (2017) and adapted to the purpose and specifications of the case study.

The first part included socio-demographic characteristics and pertained to age, gender, city of residence, country of residence, level of education, number of people living in the household, number of family members over 18 years old and monthly household income. The second part included travel behaviour questions and pertained to the location where the beach visitor is temporarily staying in Portugal, type of accommodation, type of transportation used to come to the beach, companion with whom the beach user has arrived, time that visitor usually spends on the beach, amount of money visitor spends on the beach per day and frequency with which the visitor comes to the particular beach.

The third part contained 25 beach attributes, covering beach equipment and services as follows: opportunity to observe wildlife, vegetation health, clean sand, clean seawater, biodiversity, sand dune restoration, multimodal mobility, special- needs accessibility, overcrowding, trails and boardwalks, information panel, renewable energy, security/police, medical facilities, umbrellas and sun loungers, garbage facilities, showers, public toilets, restaurants, cafés/bars, child recreation, water sports, sand sports, changing facilities and parking. Each beach attribute was measured on a four-point Likert scale (1=not important at all, $2=$ not very important, $3=$ important, $4=$ very important).

\subsection{Data analysis}

Descriptive data analysis was conducted to define the sample's profile and respondents' opinions about the importance of beach attributes. This analysis also checked for normality, skewness and outliers. Finally, a hierarchical cluster analysis was performed to identify segments of tourists who share similar characteristics based on their socio-demographic characteristics and opinions. Segmentation was based on the visitors' perceptions about the 25 beach attributes, and each segment was profiled in terms of six socio-demographic variables (age, size of household, time spent at the beach, gender, country of residence and level of education). A two-stage clustering process was applied to select the number of segments (Hair et al., 2010). The first stage involved a hierarchical procedure in which the Euclidean squared distance was the similarity measure, and Ward's method served as the agglomerative algorithm. The furthest neighbour method was also used to pre-validate an initial solution within a range of three to five segments. The final number of segments was chosen based on the dendrogram, R-squared statistic and analysis of distances between each step of the algorithm. Secondly, the kmean clustering method was performed in order to identify a definitive classification of cluster membership for each beach visitor and to find outliers differing from the whole sampling (Barai \& Dey, 2017). In terms of key identified clusters, descriptive statistics were applied to profile each cluster with respect to the evaluation of beach attributes and beach user demographic variables. In addition, to evaluate if there were significant differences between the clusters of beach visitors, comparative analyses were carried out according to socio-demographic characteristics and behaviour by using the one-way ANOVA and the Pearson Chi-square test. Each cluster was then labelled according to the dominant motivations of the cluster members.

Finally, to validate the results obtained from the cluster analysis and to determine which variables significantly discriminate between clusters, we applied a canonical discriminant analysis. In this analysis, we found linear combinations of the 25 quantitative variables that provide maximal separation between the clusters. The classification in different groups was in function of the variables elaborated for cluster analysis. In this case, a total of 200 registers, referring to the number of beach users who answered the questionnaire, were used to estimate the discriminant functions and to validate the model under study.

All the analyses were performed using IBM SPSS Statistics version 25 . A $10 \%$ level of significance was used in all statistical tests. 


\section{Empirical results}

\subsection{Beach user's profile}

Socio-demographic characteristics of beach users were analysed using descriptive statistics. The results of descriptive analysis (Table 1) show that female respondents (49.5\%) slightly outnumbered male respondents (50.5\%). The average age of tourists was 48 years old. More than half of tourists were in the age class of 51 years and more (52.5\%), followed by the age classes of $21-30$ years $(17 \%), 31-40$ years $(14.5 \%), 41-50$ years $(13.5 \%)$ and less than 21 years (2.5\%). The number of tourists from Portugal (15\%) was significantly lower than the number of international tourists (85\%). Table 1 also shows that $40.5 \%$ of respondents had received secondary education, $39.5 \%$ held a university degree, while the rest held a college degree (20\%). Indeed, education is an important factor in terms of beach assessment since educated tourists are more critical of beach service quality and attributes. In response to the question about beach visitors' monthly incomes, more than half indicated receiving more than 1000 Eur/month (58\%) and 42\% less than 1000 Eur/month. Most respondents were from small households consisting of two people (47\%), followed by one-person families (26\%). A minority of respondents were from bigger families of 3 people (13.5\%) and 4 people (10.5\%), and the lowest number of respondents were from families of 5 people (3\%). Interestingly, we found that the household size indicator is closely related to age, demonstrating that respondents older than 51 years usually live alone or with a partner, separately from their children and prefer to spend holidays in the off-peak season. On average, the majority of beach users spent half a day at the beach (36.5\%), while $29 \%$ of respondents spent only $30-60$ minutes, $23.5 \%$ spent $1-2$ hours, and the lowest number of beach users stayed all day (11\%).

Table 1 - Socio-demographic profile of respondents $(n=200)$

\begin{tabular}{|c|c|c|}
\hline Characteristic & Category & Frequency (\%) \\
\hline \multirow{2}{*}{ Gender } & Female & 49.5 \\
\hline & Male & 50.5 \\
\hline Age & $\begin{array}{l}\leq 20 \\
21-30 \\
31-40 \\
41-50 \\
\geq 51\end{array}$ & $\begin{array}{c}2.5 \\
17.0 \\
14.5 \\
13.5 \\
\mathbf{5 2 . 5}\end{array}$ \\
\hline \multirow{2}{*}{ Country of origin } & Other country & 85.0 \\
\hline & Portugal & 15.0 \\
\hline \multirow{3}{*}{ Education } & University & 39.5 \\
\hline & College & 20.0 \\
\hline & Secondary & 40.5 \\
\hline \multirow{2}{*}{ Monthly income } & $>1000$ Eur & 58.0 \\
\hline & $\leq 1000$ Eur & 42.0 \\
\hline \multirow{4}{*}{ Number of people living in the household } & 1 & 26.0 \\
\hline & 2 & 47.0 \\
\hline & 3 & 13.5 \\
\hline & $\begin{array}{l}4 \\
5 \\
\end{array}$ & $\begin{array}{c}10.5 \\
3.0\end{array}$ \\
\hline Time spent at the beach & $\begin{array}{l}30-60 \text { min } \\
1-2 \text { hours } \\
\text { Half a day } \\
\text { All day }\end{array}$ & $\begin{array}{l}29.0 \\
23.5 \\
36.5 \\
11.0\end{array}$ \\
\hline
\end{tabular}

4.2 The importance of beach environment, equipment and services variables

The average overall levels of importance of the 25 beach attributes are presented in Table 2 . In general, there is a uniformly diverse opinion regarding the importance/unimportance of variables. Table 2 shows that 12 variables were highlighted for registering high and very high average values ( $\geq 3.0$ ) and are as follows: opportunity to observe wildlife, vegetation health, biodiversity, sand dune restoration, trails and boardwalks, clean seawater, garbage facilities, public toilets, showers, cafés/bars, renewable energy and clean sand. The least importance was given to the following 13 parameters, registered at low and very low values (<3.0): multimodal mobility, special-needs accessibility, overcrowding, information panel, security/police, medical facilities, sun loungers and umbrellas, changing facilities, restaurants, children recreation, water sport, sand sport and parking. However, these are intermediate results that are important for comparing the differences obtained from further cluster analysis and for determining whether there is a significant difference between cluster members' opinions regarding the importance of variables. 
Table 2 - Average level of importance of $\mathbf{2 5}$ beach environment, equipment and services variables

\begin{tabular}{|l|c|c|}
\hline \multirow{2}{*}{\multicolumn{1}{|c|}{ Attributes }} & \multicolumn{2}{c|}{ Importance } \\
\cline { 2 - 3 } & Value & SD \\
\hline 1. Opportunity to observe wildlife & 3.79 & 0.66 \\
\hline 2. Vegetation health & 3.83 & 0.59 \\
\hline 3. Biodiversity & 3.18 & 0.94 \\
\hline 4. Sand dune restoration & 3.25 & 1.16 \\
\hline 5. Multimodal mobility & 2.97 & 1.16 \\
\hline 6. Special needs accessibility & 1.57 & 1.09 \\
\hline 7. Overcrowding & 2.04 & 1.37 \\
\hline 8. Trails and boardwalks & 3.54 & 0.90 \\
\hline 9. Information panel & 2.70 & 1.20 \\
\hline 10. Security/police & 1.76 & 1.15 \\
\hline 11. Medical facilities & 1.90 & 1.31 \\
\hline 12. Clean seawater & 3.99 & 0.12 \\
\hline 13. Sun loungers and umbrellas & 1.83 & 1.23 \\
\hline 14. Garbage facilities & 3.96 & 0.20 \\
\hline 15. Changing facilities & 2.02 & 1.29 \\
\hline 16. Showers & 3.01 & 1.31 \\
\hline 17. Public toilets & 3.82 & 0.67 \\
\hline 18. Restaurants & 2.82 & 1.35 \\
\hline 19. Cafe/bars & 3.11 & 1.24 \\
\hline 20. Children recreation & 1.40 & 0.98 \\
\hline 21. Water sport & 1.39 & 0.91 \\
\hline 22. Sand sport & 1.31 & 0.86 \\
\hline 23. Parking & 2.78 & 1.44 \\
\hline 24. Renewable energy & 3.10 & 1.21 \\
\hline 25. Clean sand & 3.97 & 0.22 \\
\hline
\end{tabular}

Note: Items classified in 4 point Likert scale from 1 - not important at all to 4 - very important / SD - Standard Deviation

\subsection{Cluster analysis results}

Based on agglomeration coefficients and dendrograms, the data were further analysed using a two-stage clustering process, which generated a number of clusters between three and five. After application of the k-mean clustering and descriptive analysis, clusters of outliers with small size were determined in a solution with five clusters. Therefore, a solution with three clusters was chosen, excluding outliers and preventing their distribution throughout all clusters. A series of Pearson Chisquare and one-way ANOVA tests were run, revealing significant differences between the three clusters. Tables 3 and 4 show the profile of each cluster with regards to the selected sociodemographic characteristics, confirming that the three clusters are significantly different in terms of age $[\chi 2=7.005 ; p=0.001]$, country of residence $[\chi 2=149.966 ; p=0.000]$ and level of education $[\chi 2=15.811, p=0.003]$. Table 5 presents the respondents' profiles in terms of their evaluation of the importance of beach attributes. Table 5 also confirms that significant differences exist between the clusters. This supports the conclusion that the respondents fall into distinct clusters according to their socio-demographic characteristics and opinions regarding beach attributes.

Table 3 - One-way ANOVA test results of cluster differences by beach user characteristics

\begin{tabular}{|l|c|c|c|c|}
\hline & $\begin{array}{c}\text { Cluster 1 } \\
(\mathbf{n}=\mathbf{1 0 2 / 5 1 \% )} \\
\text { Comfort and food } \\
\text { lovers }\end{array}$ & $\begin{array}{c}\text { Cluster 2 } \\
(\mathbf{n}=\mathbf{4 8 / 2 4 \% )} \\
\text { Young and active } \\
\text { environmentalists }\end{array}$ & $\begin{array}{c}\text { Cluster 3 } \\
\text { (n=50/25\%) } \\
\text { Sustainable } \\
\text { minimalists }\end{array}$ & $\begin{array}{c}\text { One-way ANOVA } \\
\text { F ( } \boldsymbol{p} \text {-value) }\end{array}$ \\
\hline Age & 50 & 40 & 50 & $7.005(0.001)^{* * *}$ \\
\hline The size of household & 2 & 2 & 2 & NS \\
\hline $\begin{array}{l}\text { Time spent at the } \\
\text { beach }\end{array}$ & 2.6 & 2.6 & 2.5 & NS \\
\hline
\end{tabular}

Note: NS - not significant $(p>0.10) /$ Significant levels: ${ }^{* * *} p<0.01 ; * * p<0.05 ;{ }^{*} p<0.10$.

Table 4 shows that the variable of gender does not reveal a significant difference between the three clusters $(\chi 2=0.691, p=$ $0.708)$, which means that men and women are distributed in almost equal proportions in each cluster. Therefore, an emphasis will be placed on the following variables, revealing significant differences: age, country of residence and level of education. 
Table 4 - Chi-squared test results of cluster differences by beach user characteristics

\begin{tabular}{|c|c|c|c|c|c|}
\hline & & $\begin{array}{c}\text { Cluster } 1 \\
\text { Comfort and food } \\
\text { lovers } \\
(\%) \\
\end{array}$ & $\begin{array}{c}\text { Cluster } 2 \\
\text { Young and active } \\
\text { environmentalists } \\
(\%)\end{array}$ & $\begin{array}{c}\text { Cluster } 3 \\
\text { Sustainable } \\
\text { minimalists } \\
(\%) \\
\end{array}$ & $\begin{array}{c}\text { Chi-squared } \\
\text { test } \\
\chi^{2}(p-v a l u e)\end{array}$ \\
\hline Gender & $\begin{array}{l}\text { Female } \\
\text { Male }\end{array}$ & $\begin{array}{l}53 \\
47\end{array}$ & $\begin{array}{l}56 \\
44\end{array}$ & $\begin{array}{l}60 \\
40\end{array}$ & NS \\
\hline Country of residence & $\begin{array}{l}\text { Belgium } \\
\text { Brasil } \\
\text { France } \\
\text { Germany } \\
\text { The Netherlands } \\
\text { Ireland } \\
\text { Portugal } \\
\text { Scotland } \\
\text { Sweden } \\
\text { England } \\
\text { Other }\end{array}$ & $\begin{array}{c}5.9 \\
3.9 \\
2.9 \\
3.9 \\
8.8 \\
9.8 \\
20.6 \\
5.9 \\
1.0 \\
16.7 \\
20.6 \\
\end{array}$ & $\begin{array}{c}4.2 \\
6.3 \\
4.2 \\
8.3 \\
10.4 \\
2.1 \\
0.0 \\
0.0 \\
2.1 \\
2.1 \\
60.3 \\
\end{array}$ & $\begin{array}{c}4.0 \\
0.0 \\
14.0 \\
8.0 \\
6.0 \\
0.0 \\
18.0 \\
2.0 \\
2.0 \\
12.0 \\
34.0\end{array}$ & $\begin{array}{c}149.966 \\
(0.000)^{* * *}\end{array}$ \\
\hline Level of education & $\begin{array}{l}\text { University } \\
\text { College } \\
\text { Secondary }\end{array}$ & $\begin{array}{l}30.4 \\
22.5 \\
47.1\end{array}$ & $\begin{array}{l}62.5 \\
18.8 \\
18.8\end{array}$ & $\begin{array}{l}44.0 \\
16.0 \\
40.0\end{array}$ & $\begin{array}{c}15.811 \\
(0.003)^{* * *}\end{array}$ \\
\hline
\end{tabular}

Note: NS - not significant ( $p>0.10)$ / Significant levels: ${ }^{* * *} p<0.01 ;{ }^{* *} p<0.05 ;{ }^{*} p<0.10$.

Table 5 shows the significant differences between clusters based on an evaluation of the importance of beach attributes. Hence, an emphasis will be placed on the items that emerged as nonsignificant, meaning that there are no diverse opinions regarding the importance of the following attributes: opportunity to observe wildlife, trails and boardwalks, clean seawater, garbage facilities, parking and renewable energy. The results of the mentioned items explain that independently from clustering, there is a uniform opinion about importance related to beach infrastructure, general cleanliness and aesthetics, which are significant aspects for the majority of tourists. Each cluster is discussed separately below based on its main characteristics.

Table 5 - One-way ANOVA test results of differences between clusters of beach attributes evaluation

\begin{tabular}{|c|c|c|c|c|}
\hline Attributes & $\begin{array}{c}\text { Cluster } 1 \\
\text { Comfort and } \\
\text { food lovers }\end{array}$ & $\begin{array}{c}\text { Cluster } 2 \\
\text { Young and active } \\
\text { environmentalists }\end{array}$ & $\begin{array}{c}\text { Cluster } 3 \\
\text { Sustainable } \\
\text { minimalists } \\
\end{array}$ & $\begin{array}{c}\text { One-way ANOVA F ( } p- \\
\text { value) }\end{array}$ \\
\hline Opportunity to observe wildlife & 4 & 4 & 4 & NS \\
\hline Vegetation health & 4 & 4 & 4 & $4.976(0.008)^{* * *}$ \\
\hline Biodiversity & 3 & 3 & 4 & $7.289(0.001)^{* * *}$ \\
\hline Sand dune restoration & 3 & 3 & 3 & $2.654(0.073)^{*}$ \\
\hline Multimodal mobility & 3 & 2 & 4 & $81.089(0.000)^{* * *}$ \\
\hline Special needs accessibility & 2 & 1 & 1 & $11.827(0.000)^{* * *}$ \\
\hline Overcrowding & 2 & 4 & 1 & $122.563(0.000)^{* * *}$ \\
\hline Trails and boardwalks & 4 & 4 & 4 & NS \\
\hline Information panel & 3 & 2 & 2 & $7.415(0.001)^{* * *}$ \\
\hline Security/police & 2 & 2 & 1 & $20.661(0.000)^{* * *}$ \\
\hline Medical facilities & 3 & 1 & 1 & $25.123(0.000)^{* * *}$ \\
\hline Clean seawater & 4 & 4 & 4 & NS \\
\hline Sun loungers and umbrellas & 2 & 2 & 1 & $14.081(0.000)^{* * *}$ \\
\hline Garbage facilities & 4 & 4 & 4 & NS \\
\hline Changing facilities & 2 & 3 & 2 & $6.027(0.003)^{* * *}$ \\
\hline Showers & 3 & 4 & 2 & $18.972(0.000)^{* * *}$ \\
\hline Public toilets & 4 & 4 & 4 & $3.238(0.041)^{* *}$ \\
\hline Restaurants & 4 & 3 & 1 & $153.28(0.000)^{* * *}$ \\
\hline Cafe/bars & 4 & 3 & 2 & $103.177(0.000)^{* * *}$ \\
\hline Children recreation & 1 & 2 & 1 & $11.414(0.000)^{* * *}$ \\
\hline Water sports & 1 & 2 & 1 & $10.019(0.000)^{* * *}$ \\
\hline Sand sports & 1 & 2 & 1 & $9.983(0.000)^{* * *}$ \\
\hline Parking & 3 & 3 & 3 & NS \\
\hline Renewable energy & 3 & 4 & 3 & $12.052(0.000)^{* * *}$ \\
\hline Clean sand & 4 & 4 & 4 & NS \\
\hline
\end{tabular}

Note: Items classified in 4 point Likert scale from 1 - not important at all to 4 - very important / NS - not significant ( $p>0.10)$;

Significant levels: *** $p<0.01 ; * * p<0.05 ;{ }^{*} p<0.10$.

Cluster 1: comfort and food lovers. The first cluster, labelled 'Comfort and food lovers', represented $51 \%$ of the sample. This is the most gender-balanced (i.e. $53.1 \%$ are female), and it contains more senior users, with an average age of 50 years. Almost half (47\%) have a secondary degree, and the largest number come from Portugal (21\%), followed by English tourists (17\%). They live 
in a two-person household and do not like to spend a lot of time at the beach (prefer to spend 2 hours). This cluster gives more importance to beach infrastructure and development attributes, which provide more comfort while staying on the beach. The respondents gave the highest importance to multimodal mobility, special-needs accessibility, information panel, security and medical facilities. In comparison with other clusters, these respondents consider the presence of restaurants and cafés/bars on the beach highly important. Interestingly, comfort and food lovers considered overcrowding an unimportant attribute, which is likely associated with the sampling during the low season. Finally, comfort and food lovers did not consider water and sand sport as important beach development attributes.

Cluster 2: young and active environmentalists. One-fourth of the respondents are included in the cluster called 'young and active environmentalists'. This is the youngest segment, as the average age of the respondents was 40 years. This segment comprises more women (56\%) than men. In contrast to the other segments, most members have a university degree (63\%) and spend slightly more time at the beach. This cluster includes the most Dutch tourists (10\%), but it includes representatives from all countries in the analysis list. Young and active environmentalists give more importance to cleanliness (clean seawater, clean sand, showers, public toilets and changing facilities), sustainability aspects such as overcrowding, opportunity to observe wildlife, trails and boardwalks, child recreation and renewable energy. In contrast to other clusters, young and active environmentalists gave priority to the water and sand sport attributes of the beach.

Cluster 3: sustainable minimalists. The third cluster was labelled the 'sustainable minimalists', representing $25 \%$ of the sample. This segment comprises more women (60\%) than men, and the average age of members is 50 years. The level of education in this cluster is more or less balanced - almost half of the respondents have a university degree (44\%) and slightly less have a secondary degree (40\%). This segment includes tourists from all countries, but the largest percentage are individuals from Portugal (18\%), with a further $14 \%$ from France, $12 \%$ from England and $8 \%$ from Germany. This segment is distinctive in that priority is not given to the attributes related to comfort and high development that most of the respondents considered important. Sustainable minimalists mostly value observing nature and spending time with the family. Therefore the most important attributes were related to the infrastructure which allows access to nature, such as trails and boardwalks, multimodal mobility and child recreation facilities. They also expressed their concerns about nature and its conservation and attributed great importance to the attribute of renewable energy and its consumption on the beach. As befits minimalists, the least important attributes were restaurants, cafés/bars, sun loungers and umbrellas and water and sand sports.

\subsection{Discriminant analysis results}

A discriminant analysis was performed to validate the solution of the cluster analysis and identify which variables of beach environment, equipment and services discriminate between the three clusters of beach visitors.

The discriminant analysis examined the differences among the three clusters and determined variables that significantly differentiate these clusters (Table 6), meaning that in order to classify a new beach visitor as belonging to any of the segments, we should inquire about the importance of eleven resulted attributes. The 'multimodal mobility' attribute was the highest discriminator between clusters, followed by 'information panel', 'public toilets', 'special needs accessibility', 'changing facilities', 'sand sport', 'vegetation health', 'medical facilities', 'overcrowding', 'restaurants' and 'cafés/bars'.

Two canonical discriminant functions were estimated and found to be statistically significant. Function 1 explained $60 \%$ of the variance (eigenvalue $=3.719$, Wilks' Lambda $=0.060, \chi 2=539.460$, $\mathrm{df}=22, \mathrm{p}<0.001$ ). Function 2 explained $40 \%$ of the variance (eigenvalue $=2.519$, Wilks' Lambda $=0.284, \chi 2=241.553$, $d f=10$, $\mathrm{p}<0.001)$. The analysis also calculated the degree to which respondents were correctly classified. In total, $96.5 \%$ of the 200 tourists were correctly classified, which indicated a very high accuracy rate and suggested that the solution with three clusters was correctly identified.

Table 6 - Results of variables selected by discriminant analysis to classify a new beach user in any of the clusters

\begin{tabular}{|c|c|c|c|c|c|}
\hline Attribute & Coefficients & F-statistic & Significance level & Tolerance & Discriminant ranking \\
\hline Restaurants & 0.084 & 37.264 & $p<0.001$ & 0.695 & 10 \\
\hline Overcrowding & 0.112 & 80.610 & $p<0.001$ & 0.709 & 9 \\
\hline Medical facilities & 0.072 & 18.524 & $p<0.001$ & 0.749 & 8 \\
\hline Multimodal mobility & 0.072 & 17.616 & $p<0.001$ & 0.936 & 1 \\
\hline Sand sport & 0.071 & 16.838 & $p<0.001$ & 0.810 & 6 \\
\hline Cafe/bars & 0.069 & 13.048 & $p<0.001$ & 0.687 & 11 \\
\hline Special needs accessibility & 0.065 & 6.972 & $p<0.001$ & 0.847 & 4 \\
\hline Changing facilities & 0.066 & 8.285 & $p<0.001$ & 0.845 & 5 \\
\hline Information panel & 0.065 & 7.386 & $p<0.001$ & 0.911 & 2 \\
\hline Public toilets & 0.064 & 5.566 & $p<0.001$ & 0.854 & 3 \\
\hline Vegetation health & 0.064 & 5.527 & $p<0.001$ & 0.803 & 7 \\
\hline
\end{tabular}




\section{Discussion}

Cluster analysis was conducted to identify distinct segments of beach users, characterising and defining their different profiles in function of the 25 importance items and socio-demographic characteristics. Since visitors do not constitute a homogenous population and there is a diverse array of demographics, attitudes and behaviours (Manning, 1999), according to the tourist segmentation pioneers Cohen (1972) and Plog (1977), clustering is crucial for destination management, helping to prepare marketing strategies that fit market expectations and needs through the use of information obtained from beach user questionnaires. Moreover, previous tourism research has emphasised the need for segmentation in studies aimed at producing information to support decision-making (Ramires et al., 2018; Srihadi et al., 2016; Veisten et al., 2015).

Our study has focused on the assessment of the importance of beach attributes, thus providing initial indicative results for beach managers about beach visitor segments and their priorities in terms of beach environment, equipment and services variables, which should receive focused and continuous management efforts. However, in contrast to previous segmentation studies, which mostly focused on tourism marketing and product improvement, our study placed emphasis on variables of climate change threats and regional ecological and social issues, albeit keeping balance with variables of touristic services, since the management of recreational beach services greatly depends on how the latter is perceived by tourists themselves (Chen \& Teng, 2016). Interestingly, variables of cleanliness, information availability, facilities and crowdedness are frequently utilised in segmentation studies of nature-based tourism destination visitors (McGuiness et al., 2017; Vaske et al., 2009; Veisten et al., 2015; Wade \& Eagles, 2003), and was therefore included in this research also. In this research, beach users were not asked about the importance of scenery, since according to Vaz et al. (2009), Portuguese people, unlike Welsh beach users, don't go to the beach mainly to enjoy nature.

This study has identified three main clusters of beach visitors, where gender had no significant relationship with groups. Our results have a number of similarities with the results of Srihadi et al. (2016), who found that gender was not significant while segmenting the tourism market in Jakarta. Our study's finding that beach visitor segments were significantly different in terms of education is in contrast with the findings of Ramires et al. (2018), who segmented tourists visiting cultural heritage sites, and with the findings of Albayrak and Caber (2018), who segmented participants in white-water rafting. It is well-known that specific attractions such as cultural heritage sites and adventurous and extreme water sport usually attract one particular type of tourists. However, the beach is a place where different types of tourists come. Therefore, segmentation is crucial in order to know their opinions and priorities concerning specific attributes and in order to raise the level of satisfaction. Our findings would seem to demonstrate that off-peak season beach visitors were segmented into the groups, where gender is distributed proportionally. Moreover, all group members had a union opinion about the importance of litter facilities and scenery. This confirms previous findings from a similar study in Algarve, suggesting that beach visitor attitudes have not changed (Williams \& Semeoshenkova, 2011). Indeed, beach cleanliness is an important attribute for visitors not only in Portugal but also in Italy (Newton et al., 2017; Palmisani et al., 2009), Taiwan (Chen \& Teng, 2016) and Wales (Vaz et al., 2009), and therefore it is a management issue for any beach typology (Vaz et al., 2009). Remarkably, comfort and food lovers, as well as sustainable minimalists, considered overcrowding an unimportant attribute. Nevertheless, it is the main concern in the summertime, significantly contributing to coastal erosion phenomena, and has already become a global beach management issue (Chen \& Teng, 2016; King, 2001), requiring urgent solutions.

No significant differences appeared while clustering beach visitors in terms of environmental awareness. It might be concluded that for most nationalities, nature is a priority; great importance was given to environmental attributes, such as the opportunity to observe wildlife, vegetation health, trails and boardwalks, clean seawater and clean sand. According to Palmer et al. (1998), the factors influencing concern about the environment and about ecology comes from childhood experiences of nature and from education. Indeed, as far as we know from personal interviews with beach visitors, the majority of visitors came from large urban areas, such as Glasgow, London, Stockholm, Frankfurt, Paris, or Dublin. Nevertheless, the results show how conscious beach visitors are, independently of place of origin. According to Lakatos et al. (2018), age is one of the determinants of environmental awareness. We found a significant difference in age between the three clusters. Moreover, most of them have received a university degree, which may also determine environmental awareness. However, it should be considered that the Algarve region has shown an increasing loss of ecosystems resulting from the expansion of urban areas (Vaz et al., 2012), erosion, nourishment, intensive engineering aimed at combatting erosion, beach cleaning, pollution and fisheries (Jones et al., 2009).

\section{Conclusions}

This research segments and characterises off-peak season beach visitors in the municipality of Albufeira according to a set of beach destination attributes. It identifies the importance given by beach users to those attributes, which may be used by decision-makers to choose further investments in beach services, equipment, environment and management. Three main segments, namely, young and active environmentalists, sustainable minimalists and comfort and food lovers, were identified. Young and active environmentalists as well as sustainable minimalists share behaviour patterns and prioritise environmental attributes related to biodiversity, vegetation health, sand dune restoration, trails infrastructure and information facilities. However, the largest segment, comfort and food lovers, reported slightly different behaviour and gave priority to beach infrastructure facilities, mostly to restaurants and cafés/bars. 
We have obtained satisfactory results for the young and active environmentalists cluster, which is essential since most of the beach areas have the dual mandate of conserving natural resources and providing opportunities for recreation and tourism. The most threatening factors affecting beach management are coastal erosion, urbanisation, overcrowding and ecosystem degradation. Therefore, our results reveal the consciousness of beach visitors concerning the current regional issues, which facilitates the decision making process and the risk to displease visitors with changes.

Cluster analysis allowed us to segment beach visitors and extract the main attributes according to which new beach users may be clustered. This is very important not only for future researchers but also for destination managers and local private and public businesses since during the off-peak season, every beach visitor plays a significant role in the local economy. During the off-peak season, tourist expenses are crucial to stimulate the local economy and the development of sun-and-sea destinations. Beach managers are concerned about the results of clusters, which helps them to make more accurate decisions regarding sustainable beach management and provision of services.

In general, on a wider level, further research is needed to determine the satisfactoriness of the same variables to assess the progress or regress made by beach management units. Moreover, future studies should target our research and assess beach visitors' perceptions of the most popular touristic destinations of Algarve in terms of environment, equipment and services. It is essential for municipalities such as Albufeira, where the main regional economic drivers are tourists, and segmentation of visitors' studies makes it possible to inform public and private organisations about investments in order to satisfy visitors.

\section{Acknowledgements}

The authors are thankful for the support from the Research Centre for Tourism, Sustainability and Well-being (CinTurs) [FCT Grant Number UIDP/SOC/04020/2020]. This research was funded by the Erasmus+ traineeship programme of the European Union.

\section{References}

Albayrak, T. \& Caber, M. (2018). A motivation-based segmentation of holiday tourists participating in white-water rafting. Journal of Destination Marketing and Management, 9, 64-71.

Alves, B., Ballester, R., Rigall-I-Torrent, R., Ferreira, O., Benavente, J. (2017). How feasible is coastal management? A social benefit analysis of a coastal destination in SW Spain. Tourism Management, 60, 188-200.

Andriotis, K. (2005). Seasonality on Crete: problem or a way of life? Tourism Economics, 11(2), 207-224.

Antonakakis, N., Dragouni, M., Eeckels, B. \& Filis, G. (2017). The tourism and economic growth enigma: examining an ambiguous relationship through multiple prisms. Journal of Travel Research, 58(1), 1-22.

Antunes, F. (2000). Algarve: the tourism chain and the new management of the territory. International Journal of Contemporary Hospitality Management, 12(7), 431-434.

Aucelli, P. P. C., Di Paola, G., Incontri, P., Rizzo, A., Vilardo, G., Benassai, G. Buonocore, B. \& Pappone, G. (2017). Coastal inundation risk assessment due to subsidence and sea level rise in a Mediterranean alluvial plain (Volturno coastal plain - Southern Italy). Estuarine, Coastal and Shelf Science, 198(B), 597-609.

Barreira, A. P. \& Cesário, M. (2018). Studies addressing tourists' appreciation of the same tourism destination in peak and off-peak seasons are scarce. International Journal of Tourism Research, 20, 578587.

Barai, A. \& Dey, L. (2017). Outlier detection and removal algorithm in kmeans and hierarchical clustering. World Journal of Computer Application and Technology, 5(2), 24-29.

Batista, C. M., Planas, J. A., Pelot, R. \& Núnez, J. R. (2020). A new methodology incorporating public participation within Cuba's ICZM program. Ocean \& Coastal Management, 186, 105101.

Botequilha-Leitao, A., Díaz-Varela, E. \& Aguilera-Benavente, F. (2014). Detecting multi-scale urban growth patterns and processes in the Algarve region (Southern Portugal). Applied Geography, 53, 234-245.

Bruyere, B. L., Rodriguez, D. A. \& Vaske, J. J. (2002). Enhancing Importance-Performance analysis through segmentation. Journal of Travel and Tourism Marketing, 12(1), 81-95.

Butler, R. W. (1994). Seasonality in tourism: issues and implications. In A. Seaton (Eds.), Tourism: the State of the Art (pp. 332-339). Chichester: Willey.

Cabral, P., Pires, R. \& Martins, V. N. (2012). Modelling of coastal vulnerability in the stretch between the beaches of Porto de Mós and Falésia, Algarve (Portugal). Journal of Coastal Conservation, 16, 503-510.

Chen, C. L. \& Teng, N. (2016). Management priorities and carrying capacity at a high-use beach from tourists' perspectives: A way towards sustainable beach tourism. Marine Policy, 74, 213-219.

Cohen, E. (1972). Toward a sociology of international tourism. Social Research, 39, 164-182.

Corluka, G., Mikinac, K. and Milenkovska, A. (2016). Classification of tourist season in coastal tourism. UTMS Journal of Economics, 7(1), 71-83 Dempsey, J. \& Roberston, M. M. (2012). Ecosystem services: tensions, impurities, and points of engagement within neoliberalism. Progress in Human Geography, 36 (6), 758-779.

Driver, H. E. \& Kroeber, A. L. (1932). Quantitative expression of cultural relationships. Berkeley: University of California Press.

European Commission (2014). Communication from the commission to the European parliament, the council, the European economic and social committee and the committee of the regions. A European Strategy for more growth and jobs in coastal and maritime tourism. Brussels: European Commission https://eurlex.europa.eu/LexUriServ/LexUriServ.do?uri=COM:2014:0086:FIN:EN:PD $F$ (Accessed on 2 May, 2020).

Ferreira, P. L., Gonçalves, S. P., Ferreira, L. N., Pereira, L. N., Antunes, P., Gouveia, N., Rodrigues, A., Cnhão, H. \& Branco, J. (2016). Assessing quality of life of self-reported rheumatic patients. Rheumatology International, $36,1265-1274$.

Fung, C. K. W. \& Jim, C. Y. (2015). Segmentation by motivation of Hong Kong Global Geopark visitors in relation to sustainable nature based tourism. International Journal of Sustainable Development and World Ecology, 22(1), 76-88.

Guttentag, D., Smith, S., Potwarka, L. \& Havitz, M. (2018). Why tourists choose Airbnb: a motivation-based segmentation study. Journal of Travel Research, 57(3), 342-359.

Hair, J.F., Black, W.C., Babin, B.J. \& Anderson, R.E. (2010). Multivariate Data Analysis. 7th ed., Pearson, London.

Harrill, R., Uysal, M., Cardon, P. W., Vong, F \& Dioko, L. (2010). Resident attitudes towards gaming and tourism development in Macao: growth machine theory as a context for identifying supporters and opponents. International Journal of Tourism Research, 13, 41-53.

Humphrey, S. \& Burbridge. P. (1999). Planning and management processes: sectoral and territorial cooperation. Report of thematic study D-European demonstration programme on Integrated Coastal Zone Management. Brussels: European Commission. 
INE (2018). Estatísticas do Turismo 2018. Lisbon: Instituto Nacional de Estatística.

Jones, A.L. \& Phillips, M. R. (2006). Erosion and tourism infrastructure in the coastal zone: Problems, consequences and management. Tourism Management, 27, 517-524.

Jones, A. R., Schlacher, T. A., Shoeman, D. S., Dugan, J. E., Defeo, O., Scapini, F., Lastra, M. \& McLachlan, A. (2009). Sandy-beach ecosystems: their health, resilience and management. Sandy beaches and coastal zone management - Proceedings of the Fifth International Symposium on Sandy Beaches, Rabat, Morocco.

Kantogianni, A., Tourkolias, C. H., Damigos, D. \& Skourtos, M. (2014). Assessing sea level rise costs and adaptation benefits under uncertainty in Greece. Environmental Science and Policy, 37, 61-78.

King, P. H. (2001). Overcrowding and the Demand for Beaches in Southern California. San Francisco: Department of Boating and Waterways.

Koutrakis, E., Sapounidis, A., Marzetti, S., Marin, V., Roussel, S., Martino, S., Fabiano, M., Paoli, C., Rey-Valette, H., Povh, D. \& Malvárez, C. G. (2011). ICZM and coastal defense perception by beach users: lessons from the Mediterranean coastal area. Ocean \& Coastal Management, 54(11), 821830 .

Lakatos, E. S., Cioca, L. I., Dan, V., Ciomos, A. O., Crisan, O. A. \& Barsan, G. A. (2018). Studies and investigation about the attitude towards sustainable production, consumption and waste generation in line with circular economy in Romania. Sustainability, 10(3), 865.

Lindsay, B. E., Halstead, J. M. \& Tupper, H. C. (1992). Factors influencing the willingness to pay for coastal beach protection. Coastal Management, 20, 291-302.

Loker-Murphy, L. (1997). Backpackers in Australia: a motivation-based segmentation study. Journal of Travel and Tourism Marketing, 5(4), 2345.

Manning, R. E. (1999). Studies in outdoor recreation: search and research for satisfaction (2nd ed.). Corvallis: Oregon State University Press.

Martins, V. N., Pires, R. \& Cabral, P. (2012). Modelling of coastal vulnerability in the stretch between the beaches of Porto de Mós and Falésia, Algarve (Portugal). Journal of Coastal Conservation, 16, 503-510.

Marin, V., Palmisani, F., Ivaldi, R., Dursi, R. \& Fabiano, M. (2009). Users' perception analysis for sustainable beach management in Italy. Ocean and Coastal Management, 52, 268-277.

Marzetti, S., Disegna, M., Koutrakis, E., Sapounidis, D., Marin, V., Martino, S., Roussel, S., Rey-Valette, H. \& Paoli, C. (2016). Visitors' awareness of ICZM and WTP for beach preservation in four European Mediterranean regions. Marine Policy, 63, 100-108.

McCleary, K. (1995). Applying internal marketing techniques for better festival organisation and management. Festive Management and Event Tourism, 3(1), 1-7.

McGuiness, V., Rodger, K., Pearce, J., Newsome, D. \& Eagles, P. F. J. (2017). Short-stop visitation in Shark Bay World Heritage area: an importanceperformance analysis. Journal of Ecotourism, 16(1), 24-40.

Neto, C. S., Costa, J. C. \&Martins, M. C. (2013). The meaning of mainland Portugal beaches and dunes' psammophilic plant communities: a contribution to tourism management and nature conservation. Journal of Coastal Conservation, 17, 279-299.

Newton, A., Contin, A., Greggio, N. \& Semeoshenkova, V. (2017). Development and application of an Integrated Beach Quality Index (BQI). Ocean and Coastal Management, 143, 74-86.

Nunes, M., Ferreira, Ó., Schaefer, M., Clifton, J., Baily, B., Moura, D. \& Loureiro, C. (2009). Hazard assessment in rock cliffs at Central Algarve (Portugal): A tool for coastal management. Ocean and Coastal Management, 52(10), 506-515.

Palmer, J. A., Suggate, J., Bajd, B. \& Tsaliki, E. (1998). Significant influences on the development of adults' environmental awareness in the UK, Slovenia and Greece. Environmental Education Research, 4(4), 429-444.

Palmisani, F., Fabiano, M., Ivaldi, R., Dursi, R. \& Marin, V. (2009). Users' perception analysis for sustainable beach management in Italy. Ocean and Coastal Management, 52, 268-277.
Plog, S. (1977). Why destinations rise and fall in popularity. In E. M. Kelly (Eds.), Domestic and international tourism (pp. 26-28). Wellesley, MA: Institute of Certified Travel Agents.

Ramires, A., Brandão, F. \& Sousa, A. C. (2018). Motivation-based cluster analysis for international tourists visiting a World Heritage City: the case of Porto, Portugal. Journal of Destination Marketing and Management, 8, 49-60.

Roca, E. \& Villares, M., 2008. Public perceptions for evaluating beach quality in urban and semi-natural environments. Ocean and Coastal Management, 51, 314-329.

Rodríguez-Díaz, B. \& Pulido-Fernández, J. I. (2020). Sustainability as a key factor in tourism competitiveness: a global analysis. Sustainability, 12(1), 51.

Samora-Arvela, A., Ferrão, J., Ferreira, J., Panagopoulos, T. \& Vaz, E. (2017). Diversifying Mediterranean tourism as a strategy of climate change adaptation. In H. Pinto, T. Noronha \& E. Vaz (Eds.), Resilience and Regional Dynamics (pp. 105-127). Cham: Springer.

Santos, I R., Friedrich, A. C., Wallner-Kersanach, M. \& Fillmann, G. (2005). Influence of socioeconomic characteristics of beach users on litter generation. Ocean and Coastal Management, 48, 742-52.

Scott, D., McBoyle, G. \& Schwartzentruber, M. (2004). Climate change and the distribution of climatic resources for tourism in North America. Climate Research, 27(2), 105-117.

Semeoshenkova, V. \& Newton, A. (2015). Overview of erosion and beach quality issues in three Southern European countries: Portugal, Spain and Italy. Ocean and Coastal Management, 118, 12-21.

Smith, D. G., Cragg, A. M. \& Croker, G. F. (1991). Water clarity criteria for bathing waters based on user perception. Journal of Environmental Management, 33, 285-99.

Snider, A., Luo, S., Hill, J. \& Herstine, J. (2015). Perceptions of availability of beach parking and access as predictors of coastal tourism. Ocean and Coastal Management, 105, 48-55.

Snoussi, M., Ouchani, T. \& Niazi, S. (2008). Vulnerability assessment of the impact of sea-level rise and flooding on the Moroccan coast: The case of the Mediterranean eastern zone. Estuarine, Coastal and Shelf Science, 77(2), 206-213.

Srihadi, T. F., Hortoyo, Sukandar, D. \& Soehadi, A. W. (2016). Segmentation of the tourism market for Jakarta: classification of foreign visitors' lifestyle typologies. Tourism Management Perspectives, 19, 3239.

Tampakis, S., Panagopoulos, T., Karanikola, P. \& Papadopoulos, A. (2018). Development, pollution and stakeholders' activities for the protection of the coastal and marine environment. Journal of Environmental Protection and Ecology, 19(3), 1130-1137.

Thiel, A. (2010). Institutions shaping coastal ecosystems: the Algarve case. Coastal Management, 38, 144-164.

Thompson, L. \& Schlacher, T. A. (2012). Beach recreation impacts benthic invertebrates on ocean-exposed sandy shores. Biological Conservation, 147, 123-132.

Tovar-Sánchez, A. \& Sánchez-Quiles, D. (2015). Are sunscreens a new environmental risk associated with coastal tourism? Environment International, 83, 158- 170.

Vaske, J. J., Beaman, J., Stanley, R. \& Grenier, M. (1996). ImportancePerformance and segmentation: where do we go from here? Journal of Travel and Tourism Marketing, 5(3), 225-240.

Vaske, J. J., Kiriakos, R., Cottrell, S. P. \& Khuong, M. N. (2009). Importanceperformance and segmentation: an application at a biosphere reserve in Vietnam. Journal of Travel and Tourism Marketing, 26(1), 30-41.

Vaz, B., Williams, A. T., Pereira da Silva, C. \& Philips, M. (2009). The importance of user's perception for beach management. Journal of Coastal Research, 56, 1164-1168.

Vaz, E., Painho, M., Caetano, M. \& Nijkamp, P. (2012). A multi-scenario forecast of urban change: a study on urban growth in the Algarve. Landscape and Urban Planning, 104, 201-211. 
Veisten, K., Haukeland, J. V., Baardsen, S., Degnes-Odemark, H. \& Grue, B. (2015). Tourist segments for new facilities in national park areas: profiling tourists in Norway based on psychographics and demographics. Journal of Hospitality Marketing and Management, 24(5), 486-510.

Wade, D. J. \& Eagles, P. F. G. (2003). The use of Importance-Performance analysis and market segmentation for tourism management in parks and protected areas: An application to Tanzania's national parks. Journal of Ecotourism, 2(3), 196-212.

Williams, A. T. \& Nelson, C. (1997). The public perception of beach debris. Shore and Beach, 65(3), 17-20.

Williams, A. T. \& Semeoshenkova, V. S. (2011). Beach quality assessment and management in the Sotavento (Eastern) Algarve, Portugal. Journal of Coastal Research, 57, 1282-1286.

Williams, A. T. \& Micallef, A. (2009). Beach management: Principles and practice. Earthscan.

Windgassen, S., Moss-Morris, R., Goldsmith, K., \& Chalder, T. (2018). The importance of cluster analysis for enhancing clinical practice: an example from irritable bowel syndrome. Journal of Mental Health, 27(2), 94-96. 